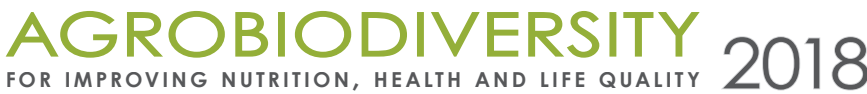

?

\section{ALLELOPATHIC AND BIOCHEMICAL CHARACTERISTICS OF THE ROOT ENVIRONMENT OF ASIMINA TRILOBA (L.) DUNAL}

\section{Pavliuchenko Nataliia*1, Klymenko Svitlana ${ }^{2}$, Dobroskok Vitaliy ${ }^{1}$, Krupa Sergiy ${ }^{1}$}

\author{
${ }^{1}$ M.M. Gryshko National Botanical Garden of Ukraine National Academy of Sciences, \\ Department of AllelopathyKyiv, Ukraine \\ ${ }^{2}$ M.M. Gryshko National Botanical Garden of Ukraine National Academy of Sciences, \\ Department of Fruit Plants Acclimatization, Kyiv, Ukraine
}

Received: 01. 11.2018 Revised: 08.11.2018 Published: 10.12. 2018

The paper is devoted to the study of the allelopathic and biochemical characteristics of the root environment of Asimina triloba (L.) Dunal (pawpaw) introduced from North America to M.M. Gryshko National Botanical Garden of NAS of Ukraine. The plants were divided into the following age groups: a) young plants (2-4 years old), b) plants of the middle age (5-7 years old), c) the old plants (14-16 years old) and d) the oldest plants (over 22 years old). Allelopathic and biochemical analyses were conducted in dynamics on phases of plant development during flowering, fruitage and the end of the growing season. Rhizosphere soil samples were collected at 0-20 cm layer. The fallow soil was used as a control. The presence of allelochemicals in root environment of $A$. triloba by modified Neubauer and Schneider method was established. As a result, the inhibition of the growth processes and accumulation of dry matter in the roots and shoots of acceptor plants with an increase in the age of pawpaw was observed. Biochemical state of the root environment was assessed by redox potential (Eh) values. The redox status varied from weakly to highly reducing soil conditions during the growing season. The lowest soil $E h$ level for the oldest plants was determined. The predominance of reduction processes in the rhizosphere soil of $A$. triloba indicates the accumulation of mobile organic compounds, which can function as allelochemicals. The content of phenolic compounds in the rhizosphere soil of $A$. triloba was 1.3-3.0 times higher than control. The concentration of phenolic allelochemicals increased with the age of plants, and also at the end of the growing season. Thus, A. triloba forms a powerful allelopathic regime of the root environment, which is due to the accumulation of free organic compounds, mainly phenolic nature.

Keywords: Asimina triloba, root environment, allelochemicals, phenolic compounds, redox potential

\section{Introduction}

Recently, in Ukraine, great attention is paid to the introduction of new and non-traditional plants into culture both for preserving biodiversity and for obtaining stable yields of high-

\footnotetext{
*Corresponding author: Nataliia Pavliuchenko, M.M. Gryshko National Botanical Garden of Ukraine National Academy of Sciences, Timiryazevska 1, 01014, Kyiv, Ukraine; $\triangle$ npavliuch@gmail.com
} 
quality production as a natural source of bioactive agents. Asimina triloba (L.) Dunal (pawpaw) is a promising new ornamental and fruit crop for dissemination on Ukraine territory, including botanical gardens, arboretums, farms, etc. Pawpaw is rich in various bioactive compounds, due to which it possesses valuable nutritional, antioxidant, insecticidal, medicinal, including anti-tumoral, properties, as well as high adaptive potential to adverse environmental factors (Cuendet et al., 2008; Farag, 2009; Pande and Akoh, 2010; Sedlacek et al., 2010; Ferreira et al., 2011; Brannan et al., 2015; Ortutu et al., 2015; Koul, 2016; Levon and Klymenko, 2016; Mangal et al., 2016; Avula et al., 2018; Nam et al., 2018a).

A. triloba belongs to the mainly tropical and subtropical family Annonaceae Juss. A. triloba is a native North American species. Pawpaw is widespread in the eastern United States, ranging from New York, and southern Michigan on the north, south to northern Florida, and west to eastern Texas, Nebraska, and Kansas; it is also present in Ontario, Canada (Hormaza, 2014). A. triloba is widely cultivated in Korea for its different parts, which contain inhibitors of cancer cells and antioxidant compounds (Nam et al., 2017; Nam et al., 2018a, b). The prerequisites for the successful introduction of new species are not only their adaptability and bioecological characteristics, but also to a large extent understanding the risks associated with allelopathic effects both in relation to other species and in monoculture (Zaimenko et al., 2017). One of the negative consequences of introduction may be the aggressive invasion of new species into natural areas. Therefore, the study of the allelopathic potential of new and non-traditional plants is actual and necessary both from a scientific and a practical standpoint. The allelopathic interactions of invasive shrub Lonicera maackii in comparison with native species A. triloba were investigated (McEwan et al., 2010). The morphometric parameters of introduced pawpaw seedlings in combination with various groups of ornamental species commonly used in Romania were studied (Szilagyi and Marian, 2011).

In view of the above mentioned, the purpose of the work was to analyse the allelopathic and biochemical characteristics of the root environment of Asimina triloba as a new fruit crop for Ukrainian horticulture.

\section{Materiall and methodology}

\section{Plant material and soil source}

The object of research was the root environment of Asimina triloba from orchard plots of M.M. Gryshko National Botanical Garden of Ukraine National Academy of Sciences. Plants were divided into the following age groups: a) young plants (2-4 years old), b) plants of the middle age (5-7 years old), c) the old plants (14-16 years old) and d) the oldest plants (over 22 years old). Rhizosphere soil samples were collected at 0-20 cm layer. The fallow soil was used as a control. The soil is dark grey podzolized.

Allelopathic and biochemical analyzes were conducted in dynamics on phases of plant development during flowering (I), fruitage (II) and the end of the growing season (III). 


\section{Allelopathic activity}

Allelopathic activity of the soil was studied by modified Neubauer and Schneider method (Black, 1993). Winter wheat (Triticum aestivum L., Poliska 90 cultivar) was used as the test plant.

\section{Biochemical analyses}

The redox potential $(E h)$ was measured in soil suspension modelling soil solution at the soil to distilled water ratio as $1: 1$ by potentiometric technique (Labuda and Vetchinnikov, 2011; Fiedler et al., 2007). Phenolic compounds were extracted from the soil by desorption method using an ion exchanger KU-2-8 $\left(\mathrm{H}^{+}\right)$(Pavliuchenko et al., 2014).

\section{Data analysis}

Experimental data were statistically analyzed using the software package Microsoft Excel.

\section{Results and discussion}

The presence of allelochemicals in the root environment of $A$. triloba was established. As a result, the inhibition of the growth processes and accumulation of dry matter in the roots and shoots of acceptor plants (Triticum aestivum) with an increase in the age of pawpaw was observed. The allelopathic activity of the root environment was the largest at the end of the growing season (Figure 1, 2). It should be noted that the rhizosphere soil of young pawpaw plants caused an insignificant allelopathic effect on test plants throughout the growing season.

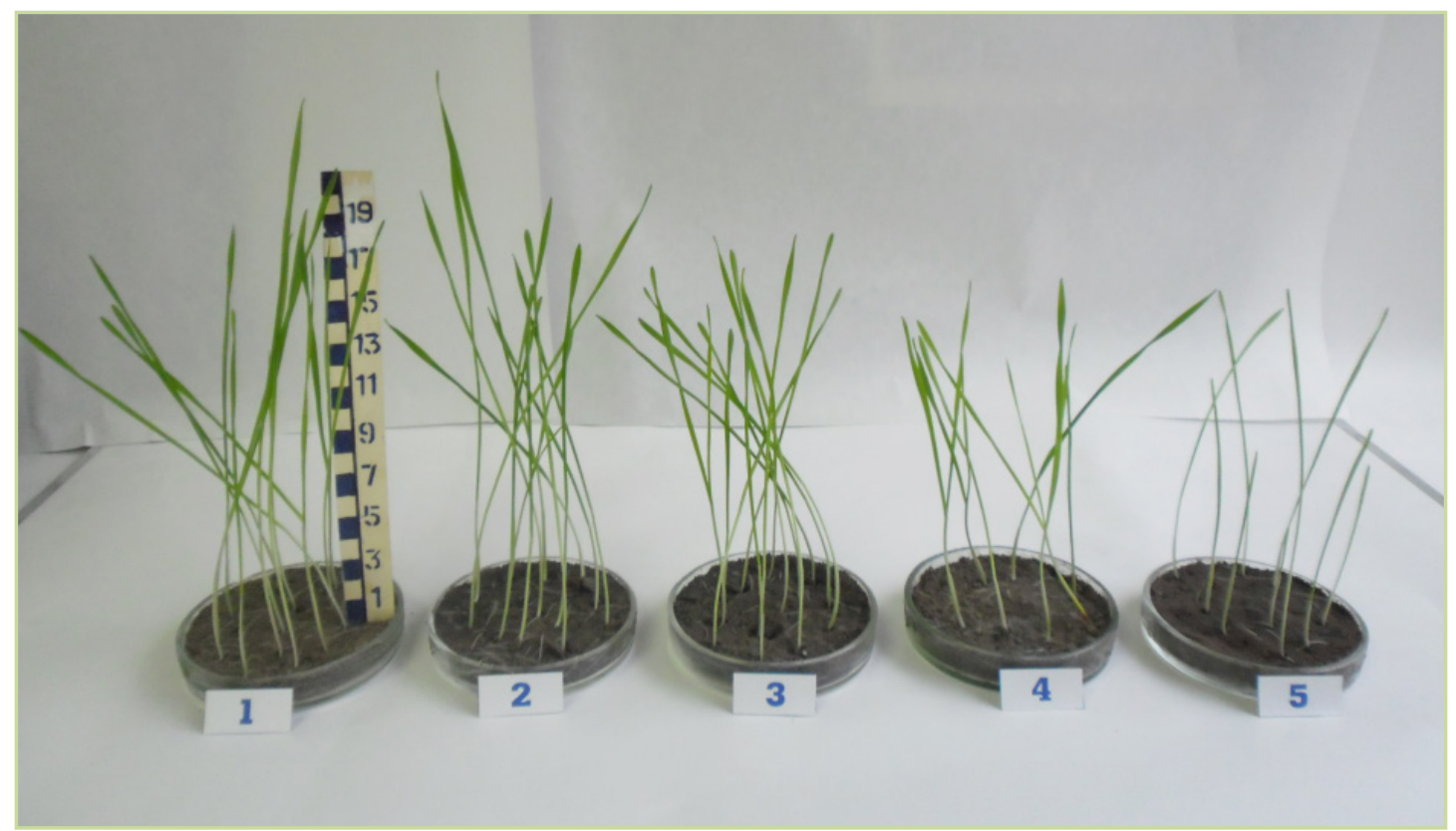

Figure 1 Allelopathic activity of root environment of Asimina triloba (test plant - Triticum aestivum): 1 - control; 2 - young plants; 3 - plants of the middle age; 4 - the old plants; 5 - the oldest plants 


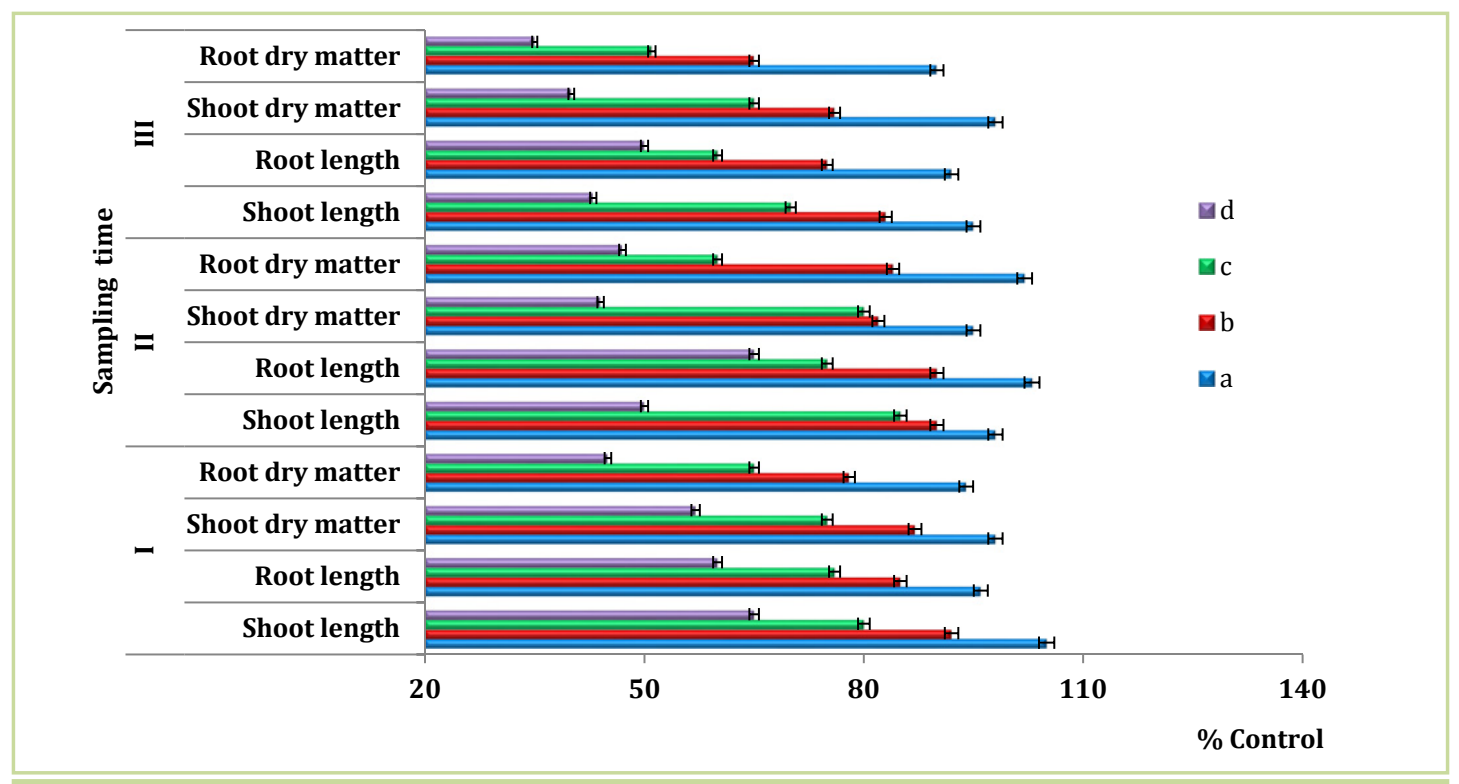

Figure 2 Allelopathic activity of root environment of Asimina triloba (test plant - Triticum aestivum),\% control: a - young plants; $\mathrm{b}$ - plants of the middle age; $\mathrm{c}$ - the old plants; $\mathrm{d}$ - the oldest plants

Biochemical state of the root environment was assessed by redox potential $(E h)$ values. Redox potential is a measure of the ratio of oxidized to reduced forms in a solution (Tokarz and Urban, 2015). Oxidation-reduction (redox) reactions in soils are mainly controlled by microbial activity, the presence of oxygen and carbon supplies (Fiedler et al., 2007; Tokarz and Urban, 2015). Eh varies depending on many factors, such as temperature, humidity, aeration, the content of organic matter, soil horizon (Husson, 2013). Plants can significantly influence $E h$ in the soil environment through root exudates (Husson, 2013). The redox potential is used as an indicator of the oxygenation status and the content of biogenic forms and toxins in the soil environment (Tokarz and Urban, 2015). Therefore, Eh fluctuations are important for the detection of phytotoxic allelochemicals in the root environment.

Weakly and moderately reducing conditions prevailed in the root environment of young plants, the middle age and the old plants of $A$. triloba. The lowest soil Eh values for the oldest plants were established. In this case, the redox status varied from moderately to highly reducing soil conditions during the growing season. The predominance of reduction processes $(E h<400 \mathrm{mV})$ in the rhizosphere soil of $A$. triloba indicates the accumulation of mobile organic compounds, which can function as allelochemicals.

Phenolic compounds are the most important and common plant allelochemicals in the ecosystems, as well as precursors of humic substances in soils (Macias et al., 2004; Li et al., 2010). The pawpaw different tissues are rich natural source of phenolic acids and flavonoids such as gallic acid, epigallocatechin, catechin, chlorogenic acid, caffeic acid, ellagic acid, epicatechin, epigallocatechin gallate, p-coumaric acid, gallocatechin gallate, ferulic acid, epicatechin gallate, rutin, catechin gallate, naringin, and quercetin (Pande and Akoh, 2010; 
Brannan et al., 2015; Ortutu et al., 2015; Levon and Klymenko, 2016; Nam et al., 2017). These phenolic compounds may be released to the root environment from $A$. triloba different parts by means of root exudation, leaching and decay of plant residues in soil. Therefore, the next stage of our research was to determine the content of phenolic compounds in the root environment of pawpaw. The content of phenolic allelochemicals in the rhizosphere soil of A. triloba was 1.3-3.0 times higher than control (Figure 3). The concentration of phenolic compounds increased with the age of plants, and also at the end of the growing season.

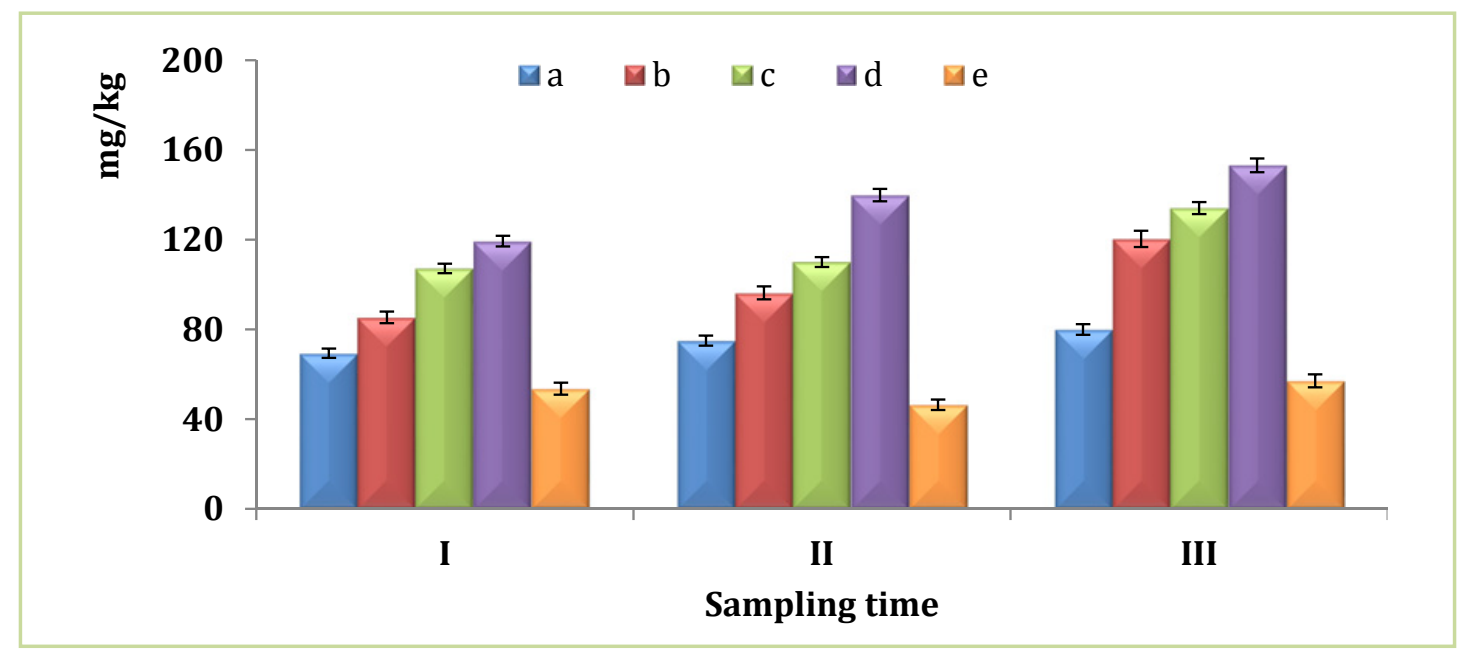

Figure 3 Phenolic compounds content in soil under Asimina triloba, mg.kg-1 : a - young plants; b - plants of the middle age; $c$ - the old plants; $d$ - the oldest plants; $\mathrm{e}$ - control

\section{Conclusions}

Thus, Asimina triloba forms a powerful allelopathic regime of the root environment, which is due to the accumulation of free organic compounds, mainly phenolic nature. Long-term cultivation of $A$. triloba enhances the intensity of soil reduction processes and its allelopathic effect on the root environment, which leads to an increase in phytotoxicity.

\section{References}

AVULA, B., BAE, J.-Y., MAJRASHI, T., WU, T.-Y., WANG, Y.-H., WANG, M., ALI, Z., WU, Y.-C., KHAN, I.A. 2018. Targeted and non-targeted analysis of annonaceous alkaloids and acetogenins from Asimina and Annona species using UHPLC-QToF-MS. In Journal of Pharmaceutical and Biomedical Analysis, vol. 159, p. 548-566. https://doi.org/10.1016/j.jpba.2018.07.030

BLACK, C.A. 1993. Soil fertility evaluation and control. CRC Press. 746 p. ISBN 0-87371-834-8.

BRANNAN, R.G., PETERS, T., TALCOTT, S.T. 2015. Phytochemical analysis of ten varieties of pawpaw (Asimina triloba (L.) Dunal fruit pulp. In Food Chemistry, vol. 168, p. 656-661. https://doi. org/10.1016/j.foodchem.2014.07.018

CUENDET, M., OTEHAM, C.P., MOON, R.C., KELLER, W.J., PEADEN, P.A., PEZZUTO, J.M. 2008. Dietary administration of Asimina triloba (Paw Paw) extract increases tumor latency in N-methylN-nitrosourea-treated rats. In Pharmaceutical Biology, vol. 46(1-2), p. 3-7. https://doi. org/10.1080/13880200701729497 
FARAG, M.A. 2009. Chemical composition and biological activities of Asimina triloba leaf essential oil. In Pharmaceutical Biology, vol. 47(10), p. 982-986. https://doi.org/10.1080/13880200902967995

FERREIRA, J.F.S., PEADEN, P., KEISER, J. 2011. In vitro trematocidal effects of crude alcoholic extracts of Artemisia annua, A absinthium, Asimina triloba, and Fumaria officinalis. In Parasitology Research, vol. 109(6), p. 1585-1592. https://doi.org/10.1007/S00436-011-2418-0

FIEDLER, S., VEPRASKAS, M.J., RICHARDSON, J.L. 2007. Soil redox potential: importance, field measurements and observations. In Advanced in Agronomy, vol. 94, p. 1-54. https://doi. org/10.1016/S0065-2113(06)94001-2

HORMAZA, J.I. 2014. The pawpaw, a forgotten North American fruit tree. In Arnoldia, vol. 72(1), p. 1323. https://www.jstor.org/stable/24706436

HUSSON, 0. 2013. Redox potential $(E h)$ and pH as drivers of soil/plant/microorganisms systems: a transdisciplinary overview pointing to integrative opportunities for agronomy. In Plant Soil, vol. 362(1-2), p. 389-417. https://doi.org/10.1007/s11104-012-1429-7.

KOUL, 0. 2016. The Handbook of Naturally Occurring Insecticidal Toxins. Wallingford: CABI. 849 p. ISBN 978-1-78064-270-3.

LABUDA, S.Z., VETCHINNIKOV, A.A. 2011. Soil susceptibility on reduction as an index of soil properties applied in the investigation upon soil devastation. In Ecological Chemistry and Engineering S, vol. 18(3), p. 333-344.

LEVON, V.F., KLYMENKO, S.V. 2016. Dynamics of the accumulation of flavonoids in overground organs of cultivars and forms of Asimina triloba (L.) Dunal. In Introdukciia Roslyn [Plant Introduction], no. 2, p. 77-81.

LI, Z.-H., WANG, Q., RUAN, X., PAN, C.-D., JIANG, D.-A. 2010. Phenolics and plant allelopathy. In Molecules, vol. 15(12), p. 8933-8952. https://doi.org/10.3390/molecules15128933.

MACIAS, F.A., GALINDO, J.C.G., MOLINILLO, J.M.G., CULTER, H.G. 2004. Allelopathy: chemistry and mode of action of allelochemicals. CRC Press. 392 p. ISBN 0-8493-1964-1.

MANGAL, M., KHAN, M.I., AGARWAL, S.M. 2016. Acetogenins as potential anticancer agents. In AntiCancer Agents in Medicinal Chemistry, vol. 16(2), p. 138-159. https://doi.org/10.2174/18715206 15666150629101827

MCEWAN, R.W., ARTHUR-PARATLEY, L.G., RIESKE, L.K., ARTHUR, M.A. 2010. A multi-assay comparison of seed germination inhibition by Lonicera maackii and co-occurring native shrubs. In Flora, vol. 205(7), p. 475-483. https://doi.org/10.1016/j.flora.2009.12.031

NAM, J.-S., JANG, H.-L., RHEE, Y.H. 2017. Antioxidant activities and phenolic compounds of several tissues of pawpaw (Asimina triloba (L.) Dunal) grown in Korea. In Journal of Food Science, vol. 82(8), p. 1827-1833. https://doi.org/10.1111/1750-3841.13806

NAM, J.-S., JANG, H.-L., RHEE, Y.H. 2018a. Nutritional compositions in roots, twigs, leaves, fruit pulp, and seeds from pawpaw (Asimina triloba (L.) Dunal) grown in Korea. In Journal of Applied Botany and Food Quality, vol. 91, p. 47-55. https://doi.org/10.5073/JABFQ.2018.091.007

NAM, J.-S., PARK, S.-Y., LEE, H.-J., LEE, S.-O., JANG, H.-L., RHEE, Y.H. 2018b. Correlation between acetogenin content and antiproliferative activity of pawpaw (Asimina triloba (L.) Dunal) fruit pulp grown in Korea. In Journal of Food Science, vol. 83(5), p. 1430-1435. https://doi. org/10.1111/1750-3841.14144

ORTUTU, S.C., AREMU, M.O., BAKO, S.S. 2015. Comparison of antioxidant capacity of mango (Mangifera indica), pawpaw (Asimina triloba) and guava (Psidium guajava) pulp extracts as different maturation stages. In Chemistry and Materials Research, vol. 7(6), p. 20-29. http://www.iiste.org/ Journals/index.php/CMR/article/view/23062/23581 
PANDE, G., AKOH, C.C. 2010. Organic acids, antioxidant capacity, phenolic content and lipid characterization of Georgia-grown underutilized fruit crops. In Food Chemistry, vol. 120(4), p. 1067-1075. https://doi.org/10.1016/j.foodchem.2009.11.054

PAVLIUCHENKO, N.A., DOBROSKOK, V.A., KRUPA, S.I. 2014. Dynamics of allelopathic activity of decay products of plant residues of Syringa josikaea Jacq. f., S. microphylla Diels. and S. persica L. In Introdukciia Roslyn [Plant Introduction], no 4, p. 77-84.

SEDLACEK, J.D., FRILEY, K.L., LOWE, J.D., POMPER, K.W. 2010. Potential of ripe pawpaw fruit extract as an insecticide and feeding deterrent for striped cucumber beetle (Coleoptera: Chrysomelidae) on squash. In Journal of Entomological Science, vol. 45(4), p. 378-384. https://doi. org/10.18474/0749-8004-45.4.378

SZILAGYI, B., MARIAN, M. 2011. Morphological and physiological features of the species Asimina triloba (L.) Dunal, introduced as an ornamental plant in Baia Mare (Maramureş County, Romania). In Analele Universităţii din Oradea - Fascicula Biologie, vol. XVIII(2), p. 168-175. http://www. bioresearch.ro/revistaen.html

TOKARZ, E., URBAN, D. 2015. Soil redox potential and its impact on microorganisms and plants of wetlands. In Journal of Ecological Engineering, vol. 16(3), p. 20-30. https://doi. org/10.12911/22998993/2801

ZAIMENKO, N., PAVLIUCHENKO, N., KLYMENKO, S., DOBROSKOK, V., KRUPA, S. 2017. Stabilization by silicon compounds of the allelopathic soil regime under perennial fruit plantations. In Agrobiodiversity for Improving Nutrition, Health and Life Quality, vol. 1, p. 533-536. http:// dx.doi.org/10.15414/agrobiodiversity.2017.2585-8246.533-536 